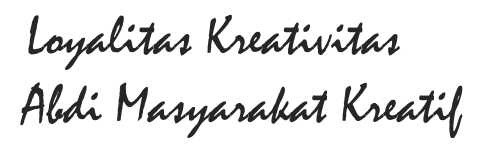

\title{
PENYULUHAN PENINGKATAN NILAI JUAL PRODUK INDUSTRI RUMAH TANGGA MELALUI TEKNOLOGI PENGEMASAN DAN PEMASARAN DI RT.01 RW.02 KELURAHAN PONDOK PETIR.
}

\author{
Aceng Abdul Hamid dan Nurselvi \\ Dosen Program Studi Teknik Industri, Fakultas Teknik, Universitas Pamulang, Tangerang \\ dosen00958@unpam.ac.id , dosen02045@unpam.ac.id
}

\begin{abstract}
ABSTRAK
Pengabdian Kepada Masyarakat (PKM) merupakan salah satu Tridharma Perguruan Tinggi yang wajib dilakukan oleh setiap dosen di Universitas Pamulang. Kegiatan PKM bertujuan membantu masyarakat sekitar kampus dengan menerapkan bidang keilmuan dosen. RT.001/RW.02 Kelurahan Pondok Petir, Kecamatan Bojongsari,Kota Depok, Jawa Barat merupakan Rukun Tetangga yang terdapat di Kelurahan Pondok Petir dengan Ketua RT Bapak Muhammad Imron. Masa pandemic ini masyarakat masih terus berusaha untuk mempertahankan keadaan ekonominya agar tetap berjalan sebagaimana mestinya. Kegiatan PKM ini bertujuan untuk membantu warga RT.001/RW.02 dalam berinovasi dengan cara menggali potensi yang ada guna mensejahterakan kehidupan keluarga pada khususnya dan masyarakat pada umumnya. Secara khusus tujuan kegiatan PKM (1) meningkatkan nilai jual produk rumah tangga hasil produksi warga dengan cara selalu berinovasi untuk memberi nilai tambah melalui Teknologi Pengemasan dan promosi (2) Memperkaya pengetahuan warga tentang teknologi pengemasan dan promosi saat ini (3) Memberikan pemahaman strategi pemasaran yang sesuai dengan masa sekarang ini. Kegiatan PKM ini dilakukan dengan peninjauan lokasi rencana PKM dan mengetahui permasalahan yang ada di lokasi tersebut dengan cara brainstorming antara dosen dan beberapa pemuka masyarakat. Kemudian TIM PKM menawarkan solusi dari permasalahan yang ada dan disetujui maka dilakukanlah kegiatan PKM ini.
\end{abstract}

Kata Kunci : Teknologi pengemasan, pemasaran, Produk Industri rumah tangga

\section{ABSTRACT}

Community Service (PKM) is one of the Tridharma of Higher Education that must be carried out by every lecturer at Pamulang University. PKM activities aim to help the community around the campus by applying the scientific fields of lecturers. RT.001/RW.02 Pondok Petir Village, Bojongsari District, Depok City, West Java is a Neighborhood Unit located in Pondok Petir Village with the Head of RT Mr. Muhammad Imron. During this pandemic, people are still trying to maintain their economic condition so that it continues to run as it should. This PKM activity aims to help residents of RT.001/RW.02 in innovating by exploring the existing potential for the welfare of family life in particular and society in general. In particular, the objectives of PKM activities (1) increase the selling value of household products produced by residents by always innovating to provide added value through packaging and promotion technology (2) Enriching residents' knowledge about current packaging and promotion technology (3) Providing understanding of marketing strategies that fits the present. This PKM activity is carried out by reviewing the location of the PKM plan and knowing the problems that exist in that location by way of brainstorming between lecturers and several 


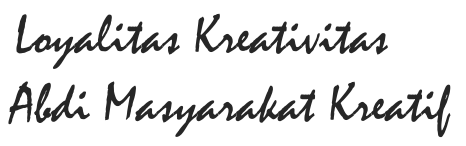

P-ISSN 2722-2101, E-ISSN 2722-4201

Program Studi Ekonomi Manajemen Universitas Pamulang

Jurnal LOKABMAS Kreatif Vol.02,No.03.Nov 2021 Hal.79-84

Email:jurnalkreatif.manajemen@gmail.com

community leaders. Then the PKM TEAM offered a solution to the existing problems and it was agreed that this PKM activity was carried out.

\section{Keywords: Packaging technology, marketing, home industry products}

\section{A. Pendahuluan}

RT.01 RW.02 merupakan Rukun Tetangga yang terdapat di Kelurahan Pondok Petir Bojongsari kota Depok dengan ketua RT Bapak Muhammad Imron. Masyarakat pondok petir khususnya ibu rumah tangganya membuat produk olahan pangan seperti jajanan pasar, donat, cimol, buah-buahan, brownis, kue ulang tahun di rumah untuk dijual bagi kalangan terbatas seperti tetangga, teman sekolah anak dan lainnya. Misalnya jajanan pasar biasanya di jual di gerai jajanan pasar atau pesanan dari warga lain yang lagi mengadakan hajatan. Namun sejak masa pandemic ini daya beli warga menjadi turun karena berkurangnya penghasilan sehingga ibu rumah tangga penjual kue harus memutar otak agar dagangan mereka tetap laku. Apabila dibiarkan berlarut-larut situasi ini akan membuat banyak hal yang terjadi dan berdampak kurang baik nantinya.

Pengemasan merupakan factor yang penting dalam persaingan dunia bisnis saat ini, dimana kemasan fungsinya tidak hanya tentang menjaga kualitas teknis produk tapi juga sebagai identitas produk. Cara pengemasan dan labeling yang baik dan menarik sangat diperlukan dalam mendukung produk pangan, namun belum semua produsen Usaha Mikro Kecil dan Menengah (UMKM) dapat menerapkannya (Semariyani, 2019). Menurut Semariyani (2019) perkembangan kemajuan UMKM terhambat karena kemasan produk dan labelingnya dimana bahan pengemas, desain bentuk kemasna, desain label dan biaya pembuatan kemasan itu sendiri.

Teknologi pengemasan merupakan suatu system yang saling terkoordinasi untuk menyipakna bahan menjadi siap di transportasikan, didistribusikan, dijual, disimpan, dijual dan dipakai oleh konsumen. Wadah atau pembungkus berfungsi untuk mengurangi kerusakan, melindungi produk didalamnya dari kontaminan maupun gangguan fisik (gesekan, benturan dan getaran). Disamping itu pengemasan produk berfungsi untuk memudahkan penyimpanan berdasarkan bentuknya dan saat ini kemasan juga berfungsi sebagai media promosi karena kemasan saat ini berfungsi juga untuk meningkatkan daya Tarik pembeli karena bentuk, bahan kemasan dan warna kemasan.

Menurut Irrubai, dkk (2016), beberapa industri rumah tangga dalam bentuk UKM saat ini masih memiliki keterbatasan dalam aspek kualitas, khususnya tentang strategi kemasan dan marketing. Penampilan produk sangat ditentukan oleh Labeling dan Packaging. Pandangan pertama konsumen sangat menentukan pilihan para konsumen sehingga penampilan produk sangat penting untuk menarik minat konsumen di pasaran.

Dari penjelasan tentang pengemasan masalah di lapangan saat ini masyarakat masih belum mengoptimalkan potensi yang terdapat dalam Pengemasan dan pemasaran produk hasil Industri Rumah Tangga meraka. Masyarakat hanya mengemas makanan secara minimalis seperti di taruh di wadah plastic besar dan dijual dengan kantong kresek. Padahan dengan inovasi pengemasan yang lebih baik produk bias dijual lebih mahal dan dijual di banyak tempat.

Kesadaran untuk pentingnya pengemasan dalam menjual produk harus ditingkatkan dan didukung karena dapat mendukung bahkan menopang perekonomian keluarga pada khususnya dan meningkatkan kesejahteraan masyarakat pada umumnya. Serta masyarakat dituntut dapat berinovasi untuk memenuhi kebutuhan keluarga tanpa memberatkan 


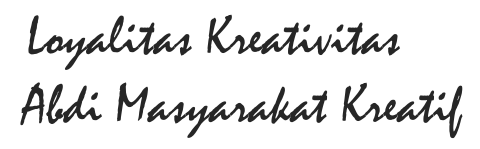

pengeluaran keluarga. Kegiatan ini bertujuan agar setiap keluarga dapat secara mandiri mencukupi kebuuhan hidupnya dengan cara berwirausaha.

PKM merupakan kegiatan wajib dosen yang dilakukan minimal satu kali tiap semester untuk memenuhi salah satu Tri Dharma Perguruan Tinggi yaitu Pengabdian Kepada Masyarakat. Pada kegiatan PKM ini kami berencana mengajarkan Teknologi Pengemasan sederhana dan strategi promosi saat ini di RT.01 RW.02.

Kegiatan PKM ini juga di sisipkan pengetahuan tentang strategi memasarkan produk makanan hasil industry rumah tangga secara online agar menarik minat pembeli. Sebelum menjual produk maka ditentukan terlebih dahulu segmen pasar. Segmen pasar yang dituju untuk produk adalah remaja dan dewasa baik itu kalangan penyuka makanan ringan atau masyarakat pada umumnya. Dalam pelatihan nanti juga kana diutarakan bagaimana penggunaan social media, menggunakan jasa influencer, berjualan di market place, mengikuti even, strategi bundling, menggunakna aplikasi dan bagaimana agar bias terus berinovasi.

Untuk membantu peningkatan penjualan maka harus didukung oleh strategi pemasaran yang baik dan benar. Dalam kegiatan ini masyarakat tidak hanya diberi penyuluhan tentang teknologi pengemasan produk juga tentang strategi promosi yang terbaru saat ini. Dengan adanya kegiatan PKM ini diharapkan dapat membantu warga RT.001 RW.02 Kelurahan Pondok Petir dalam menggali potensi yang ada dan membantu perekonomian masyaratknya.

\section{B. Rumusan Masalah}

Rumusan masalah kegiatan PKM ini secara khusus yaitu :

1. Bagaimana meningkatkan nilai jual produk rumah tangga hasil produksi warga dengan cara selalu berinovasi untuk memberi nilai tambah melalui Teknologi Pengemasan dan promosi?

2. Bagaimana Memperkaya pengetahuan warga tentang teknologi pengemasan dan promosi saat ini?

3. Bagaimana Memberikan pemahaman strategi pemasaran yang sesuai dengan masa sekarang ini.

\section{Tujuan Kegiatan}

Tujuan umum kegiatan PKM membantu warga RT.001/RW.02 dalam berinovasi dengan cara menggali potensi yang ada guna mensejahterakan kehidupan keluarga pada khususnya dan masyarakat pada umumnya .

Secara khusus tujuan kegiatan PKM adalah:

1. Meningkatkan nilai jual produk rumah tangga hasil produksi warga dengan cara selalu berinovasi untuk memberi nilai tambah melalui Teknologi Pengemasan dan promosi?

2. Memperkaya pengetahuan warga tentang teknologi pengemasan dan promosi saat ini?

3. Memberikan pemahaman strategi pemasaran yang sesuai dengan masa sekarang ini.

\section{Manfaat Kegiatan}

Manfaat umum kegiatan PKM membantu warga RT.001/RW.02 dalam berinovasi dengan cara menggali potensi yang ada guna mensejahterakan kehidupan keluarga pada khususnya dan masyarakat pada umumnya. Secara khusus Manfaat kegiatan PKM adalah:

1. Membangkitkan jiwa wirausaha warga

2. Menambah keterampilan warga

3. Memberikan pemahaman strategi pemasaran

\section{E. Pemecahan Masalah}

Untuk memecahkan masalah dalam kondisi seperti saat ini adalah warga dituntut untuk selalu belajar, berinovasi, mandiri dan mampu 


\section{Loyalitas Kreativitas \\ Aldi Masyarakat Kreatif \\ P-ISSN 2722-2101, E-ISSN 2722-4201 \\ Program Studi Ekonomi Manajemen Universitas Pamulang \\ Jurnal LOKABMAS Kreatif Vol.02,No.03.Nov 2021 Hal.79-84 \\ Email:jurnalkreatif.manajemen@gmail.com}

beradaptasi dengan keadaan serta lingkungan.

Kegiatan penyuluhan yang diberikan kepada beberapa perwakilan warga khususnya ibuibu dianggap tepat sebagai solusi permasalahan ini. Untuk lebih detail dan jelas dapat dilihat pada

\section{Gambar 1.}

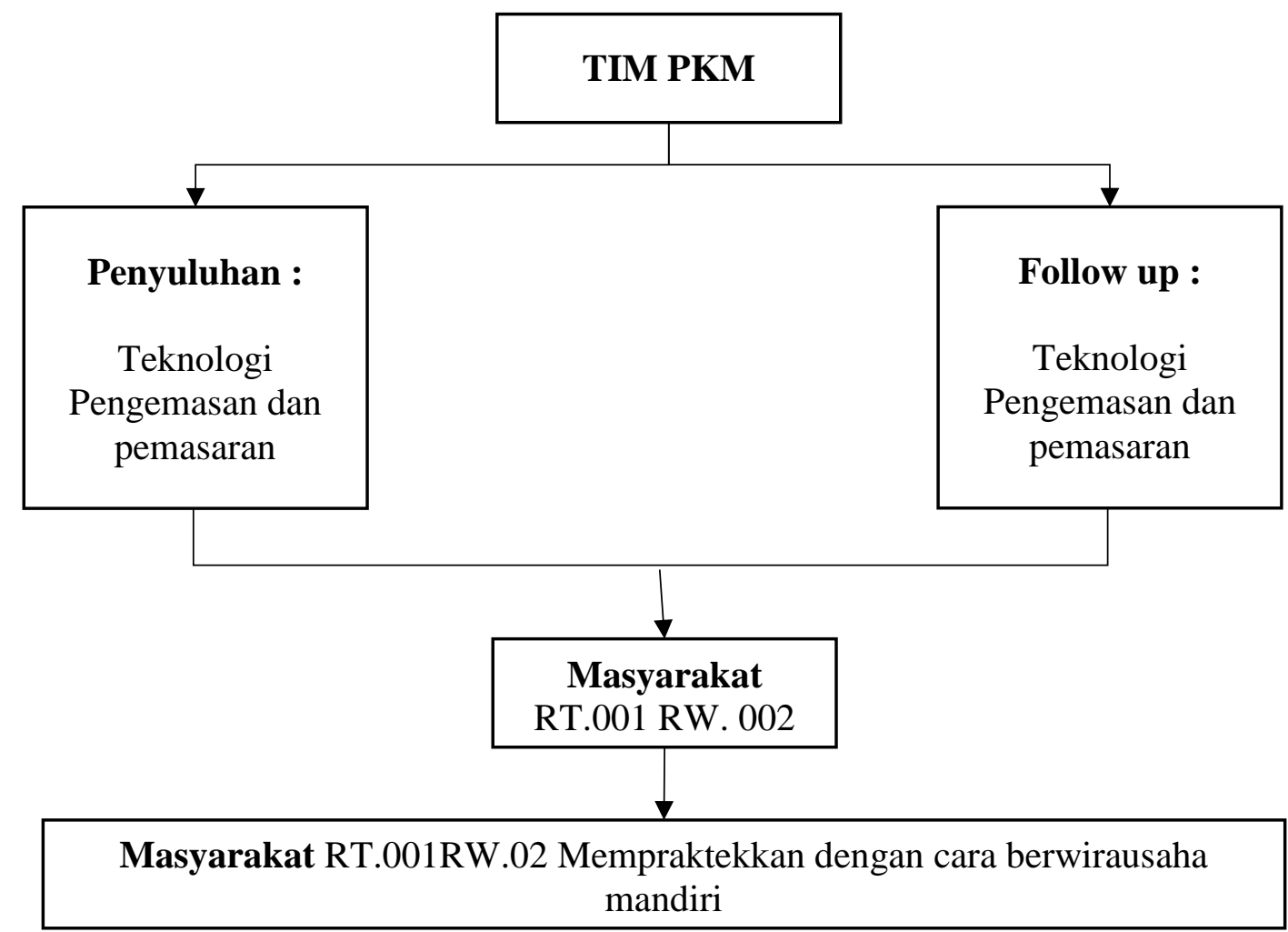

Gambar 1. Skema Pelaksanaan Kegiatan Pengabdian Masyarakat

Kegiatan pengabdian masyarakat ini disusun berdasarkan survey pendahuluan oleh tim PKM ke lokasi dan wawancara kepada perwakilan masyarakat RT.001RW.02 Pondokpetir. Berdasarkan pengamatan dilapangan menunjukkan masyarakat RT.001RW.02 Pondokpetir masih sedikit yang berusaha mandiri karena terbatasnya pengetahuan dan keterampilan masyarakatnya, disamping itu keterbatasan informasi masyarakat juga mempengaruhi.
Kegiatan ini dibuat melalui beberapa tahapan :

1. Identifikasi permasalahan

2. Pemetaan permasalahan

3. Pemilihan prioritas masalah

4. Implementasi kegiatan

5. Pengawasan kegiatan

\section{F. Tinjauan Pustaka}

1. Pengemasan 


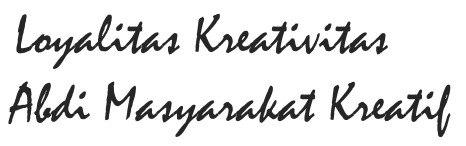

P-ISSN 2722-2101, E-ISSN 2722-4201

Program Studi Ekonomi Manajemen Universitas Pamulang

Jurnal LOKABMAS Kreatif Vol.02,No.03.Nov 2021 Hal.79-84

Email:jurnalkreatif.manajemen@gmail.com

Pengemasan merupakan salah satu cara melindungi produk pangan agar tidak rusak saat didistribusikan dan disimpan (Maimunah, 2018). Budaya kemasan sebenarnya telah dimulai sejak manusia mengenal sistem penyimpanan bahan makanan. Cara-cara pengemasan sangat erat berhubungan dengan kondisi komoditas atau produk yang dikemas serta cara transportasinya. Pada prinsipnya pengemas harus memberikan suatu kondisi yang sesuai dan berperan sebagai pelindung bagi kemungkinan perubahan keadaan yang dapat memengaruhi kualitas isi kemasan maupun bahan kemasan itu sendiri.

2. Promosi

Promosi adalah upaya untuk
memberitahukan menawarkan produk atau jasa dengan tujuan menarik calon konsumen untuk membeli atau mengkonsumsinya.Bauran promosi adalah berbagai cara atau upaya dalam mempromosikan suatu produk yang sama agar dapat memperoleh hasil yang maksimal dan memuaskan.

3. Produk Industri Rumah Tangga

Secara etimologi kata industri berasal dari bahasa Inggris industry yang berasal dari bahasa Prancis kuno industrie yang artinya aktivitas atau kerajinan. Saat ini secara spesifik industry adalah bidang yang menggunakan keterampilan, ketekunan kerja dan penggunaan alat-alat dibidang pengolahan hasil bumi dan distribusi sebagai dasarnya. Usaha industry adalah suatu unit kesatuan usaha yang melakukan kegiatan ekonomi yang bertujuan untuk menghasilkan barang dan jasa yang terletak pada bangunan atau lokasi tertentu, memiliki catatan administrasi mengenai produksi dan struktur biaya serta ada seseorang atau lebih yang bertanggung jawab atas usaha tersebut (Liana, 2008)

\section{G. Metode Pelaksanaan}

Metode yang akan digunakan dalam kegiatan pengandian Massyarakat ini adalah adalah metode penyampaian materi secara langsung. Metode penyampaian materi dilakukan melalui dua cara yaitu secara langsung dan follow up kegiatan menggunkan aplikasi google meet. Penyampaian materi digunakan untuk menyampaikan materi mengenai Teknologi pengemasan pangan dan strategi promosi sederhana. Kemudian dilanjutkan dengan sesi diskusi bertukar pikiran dan Tanya jawab.

\section{H. Hasil dan Pembahasan}

PKM ini dilakukan oleh dosen Teknik Industri Universitas Pamulang Tangerang Selatan kepada beberapa warga masyarakat Pondok petir, Bojongsari, Depok. PKM dilakukan oleh Dr. Aceng abdul Hamid, S.T.,M.M dan Nurselvi S,T.P., M.Sc serta dibantu oleh dua orang mahasiswa dengan judul "Penyuluhan Peningkatan Nilai Jual Produk Industri Rumah Tangga Melalui Teknologi Pengemasan dan Pemasaran di RT. 01 RW.02 Kelurahan Pondok Petir"

Peserta PKM merupakan warga yang memiliki usaha kuliner skala rumah tangga yang biasanya memasarkan produknya dengan cara menitipkan ke pedagang yang berjualan di pasar, berjulan buah-buhan segar melalui social media, juga ada yang sudah mulai jualan madu di Tokopedia, ada juga yang mencoba berjualan donat atau kue ulang tahun melalui wa story, atau yang masih memulai membuat konten di youtube dengan membuat resep-resep masakan simple. Pada kesimpulannya peserta PKM ini sudah memiliki usaha namun terkadang memiliki masalah dalam pengemasan produk yang kurang tepat sehingga produk sampai ke tangan konsumen dalam keadaan yang kurang baik. Sedangkan kita ketahui jika saat ini pengemasan merupakan hal yang urgen dalam menjual roduk kepada konsumen.

Kegiatan PKM dilakukan melalui offline (dengan pembatasan jumlah peserta) dan 
Loyalitas Kreativitas
Aldi Masyarakat Kreatif

follow up secara online berhubung lonjakan kasus covid 19 yang tinggi pada saat rencana pelaksanaan PKM berlangsung. Secara offline PKM ini dilakukan dengan cara berdiskusi antara dosen (Nurselvi, S.T.P.,M.Sc) dengan peserta secara langsung (dengan prokes yang cukup baik, seperti jaga jarak saat diskusi), berdiskusi langsung ini bertujuan agar peserta bebas mengemukakan masalah yang dihadapinya dalam mengemas produknya hingga sama-sama didapat kesimpulan yang diinginkan bersama dengan teknologi yang sederhana namun dengan hasil yang lebih baik.

Setelah diadakan kegiatan diskusi masalah cara pengemasan kemudian satu minggu kemudian diadakan kembali follow up secara online bersama Dr. Aceng Abdul Hamid dan beberapa mahasiswa Teknik Industri Universitas Pamulang.

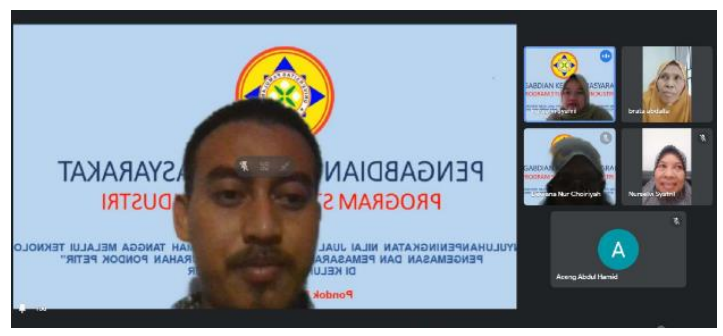

Gambar 2. Follow up kegiatan pengabdian oleh Dr. Aceng Abdul Hamid, S.T. M.M.

Dengan adanya kegiatan ini diharapkan adanya sinergi antara civitas akademika dengan masyarakat sekitar, berbagi ilmu pengetahuan yang berguna bagi masyarakat khususnya keterampilan yang berguna dalam kondisi pandemic untuk menopang perekonomian keluarga.

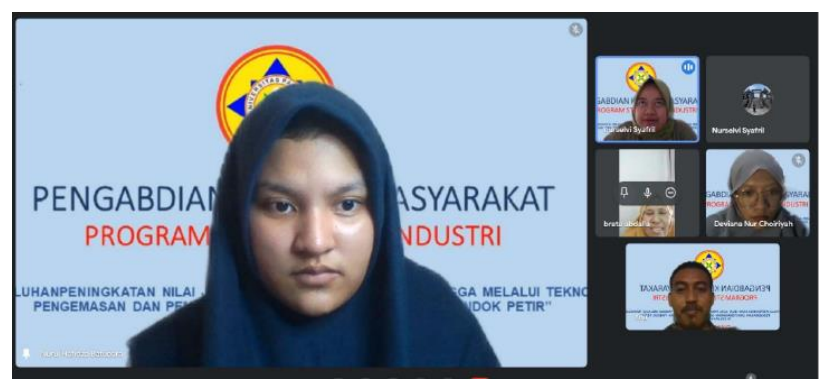

Gambar 3. Pemandu acara oleh Nurul (Mahasiswa Teknik industri)

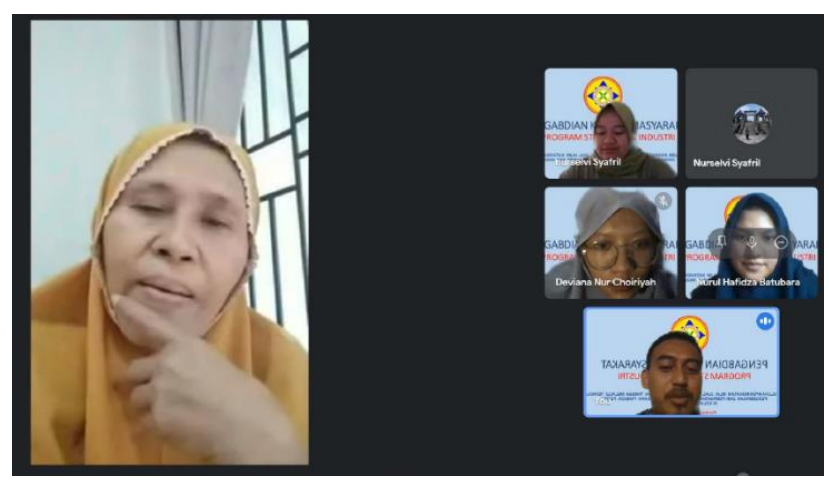

Gambar 4. Peserta memberikan tanggapan

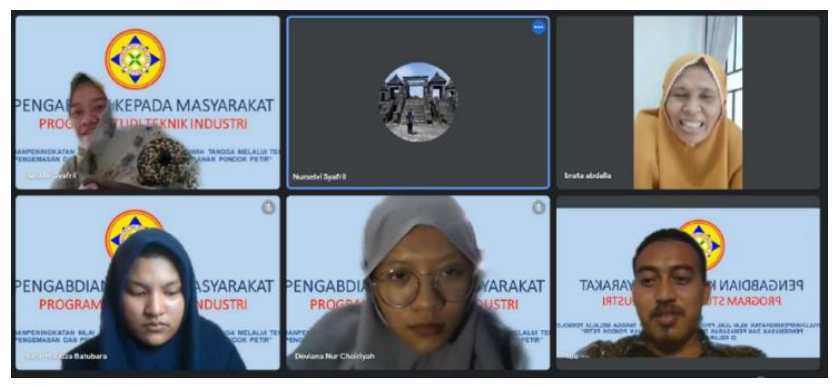

Gambar 5. Peserta Follow up kegiatan PKM dan unjuk produk (Donat Kekinian)

Penyerahan sertifikat kepada RT 001/RW 002 dimana dari Tim PKM di wakilkan oleh Nurselvi, S.T.P.,M.Sc. 


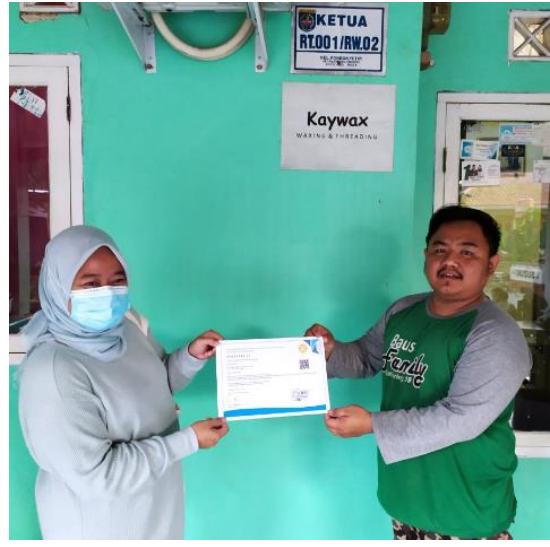

Gambar 6. Penyerahan sertifikat PKM oleh Ketua RT 01 RW 02 Kelurahan Pondok Petir

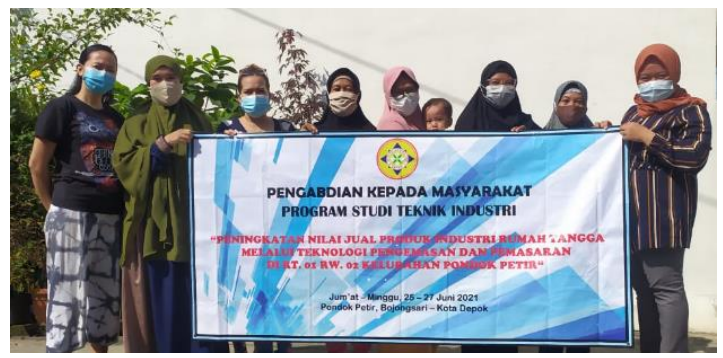

Gambar 8. Foto bersama Offline

\section{Kesimpulan}

Pelaksanaan kegiatan Pengabdian Kepada Masyarakat oleh lembaga Penelitian dan Pengabdian Masyarakat (LPPM) Universitas Pamulang yang dilakukan oleh dosen-dosen Teknik Industri ini berjalan dengan lancar dan mendapat sambutan yang positif dari Warga RT.001/RW.02 Dari kegiatan PKM ini dapat ditarik beberapa kesimpulan :

1. Kegiatan PKM ini dapat membangkitkan jiwa wirausaha warga.

2. Kegiatan PKM ini menambah pengetahuan warga RT.001/RW.02.

3. Kegiatan PKM ini memberikan pemahaman mengenai teknologi pengemasan dan strategi pemasaran yang sesuai dengan masa sekarang ini.

\section{J. Daftar Pustaka}

https://id.wikipedia.org/wiki/Promosi_(pema $\underline{\text { saran) }}$
Elburdah, R. P., Pasaribu, V. L. D., Rahayu, S., Septiani, F., \& Metarini, R. R. A. (2021). MOMPRENEUR PENOPANG PEREKONOMIAN KELUARGA DI MASA PANDEMI COVID-19 DENGAN BISNIS ONLINE PADA KELURAHAN PONDOK BENDA. Abdi Laksana: Jurnal Pengabdian Kepada Masyarakat,2(1), 75-82

Kimbal.R.W. 2015. Modal Sosial dan Ekonomi Industri Kecil : Sebuah Studi Kualitatif. Yogyakarta: Depublis.

Lie Liana. 2008. Pembinaan dan pengembangan usaha kecil sebagai sarana Memperkokoh Struktir Perekonomian Nasional. Semarang. Jurnal Bisnis dan ekonomi. Vol 15 No. 2. Fakultas Ekonomi, Universitas Stikubank Semarang.

Pasaribu, V. L. D., Agrasadya, A., Shabrina, N., \& Krisnaldy, K. (2020). Menjadi Enterpreneur Muda Yang Memiliki Jiwa Leadership Untuk Menghadapi Masa Depan. Abdi Laksana: Jurnal Pengabdian Kepada Masyarakat, 1(1).

Pasaribu, V. L. D., Susanti, F., \& Hartuti, E. T. K. (2019). Memotivasi Siswa dan Siswi SMK Letris Indonesia di Dalam Menentukan Pilihan Untuk Melanjutkan Pendidikan Atau Bekerja Setelah Lulus Sekolah. Jurnal Pengabdian Dharma Laksana, 1(2), 161-172.

Pasaribu, V. L. D., Sulaiman, S., Sutiman, S., Thaharudin, T., \& Purnomo, B. Y. (2020). Pengenalan Letak Posyandu Terdekat Dikelurahan Pisangan Dengan Manajemen Pemasaran Revolusi 4.0 Untuk Meningkatkan 


\section{Loyalitas Kreativitas Aldi Masyarakat Kreatif}

P-ISSN 2722-2101, E-ISSN 2722-4201

Program Studi Ekonomi Manajemen Universitas Pamulang Jurnal LOKABMAS Kreatif Vol.02,No.03.Nov 2021 Hal.79-84

Email:jurnalkreatif.manajemen@gmail.com
Pengetahuan Masyarakat Letak Dan Fungsi Posyandu Terdekat Pada Kelurahan Pisangan. Dedikasi Pkm, 1(1), 105-110.

Pasaribu, V. L. D., Oktrima, B., Prabowo, B., Arianto, N., \& Haryoko, U. B. (2020). Progam Pendampingan Dan Penyelenggaraan Pendidikan Anak Pada Usia Dini Terhadap Prestasi Belajar Dilingkungan Rt 020 Rw 009. Kel Giri Peni. Kec Wates. Yogyakarta. Jurnal Lokabmas Kreatif, 1(1), 71-75.

Pasaribu, V. L. D., Jannah, M., Fazar, M., Putra, S. P., Monalisa, M., \& Sofa, M. (2021). MENINGKATKAN

PRODUKTIVITAS USAHA DIMASA PANDEMI PADA IBU PKK RT 004/003 KELURAHAN SAWAH BARU CIPUTAT, TANGERANG SELATAN. Abdi Laksana: Jurnal Pengabdian Kepada Masyarakat, 2(2), 295-301

Pasaribu, V. L. D., Yuniati, H. L., Pranata, R., Sembayu, R., Purba, S. M., \& Nurbayani, T. T. A. (2021). MANAJEMEN KEUANGAN UNTUK MENGHADAPI DAN BERTAHAN DI ERA COVID 19. Jurnal Abdimas Tri Dharma Manajemen, 2(2), 12-18.

Pasaribu, V. L. D., Dwiyatni, A., Sabina, C., Ridwan, M., Gunawan, D. D., \& Noviani, B. C. (2021). EVALUASI PENERAPAN 3M DIMASA PANDEMIC COVID 19. Jurnal Abdimas Tri Dharma Manajemen, 2(2), 54-60.

Pasaribu, V. L. D., Syafei, A. N., Farhan, A., Aufaizah, A., Irani, C., \& Firtiayani, S. R. (2021). PENGARUH DISPLIN PROTOKOL KESEHATAN

\section{TERHADAP PENCEGAHAN PENULARAN VIRUS COVID- 19. Jurnal Abdimas Tri Dharma Manajemen, 2(2), 91-98.}

Pasaribu, V. L. D., Septiani, F., Rahayu, S., Lismiatun, L., Arief, M., Juanda, A., ... \& Rahim, R. (2021). Forecast Analysis of Gross Regional Domestic Product based on the Linear Regression Algorithm Technique.

Pasaribu, V. L. D., Priadi, A., Anismadiyah, V., Rahayu, S., \& Maduningtias, L. (2021). PENYULUHAN KREATIF DAN INOVATIF MENINGKATKAN MUTU PRODUKSI UMKM DI DESA BELEGA KABUPATEN GIANYAR. Pro Bono Jurnal Pengabdian Kepada Masyarakat, 1(02).

Pasaribu, V. L. D. (2021). PELATIHAN BERBASIS ONLINE DI ERA COVID19. Jurnal Abdimas Tri Dharma Manajemen, 2(3), 26-32.

Pasaribu, V. L. D., \& Setyowati, R. (2021). ADAPTASI KEHIDUPAN NEW NORMAL PADA MASA PANDEMI COVID-19 DIYAYASAN PONDOK PESANTREN DAN PANTI ASUHAN NURUL IKHSAN KECAMATAN SETU, KOTA TANGERANG SELATAN. Jurnal Lokabmas Kreatif: Loyalitas Kreatifitas Abdi Masyarakat Kreatif, 2(2), 82-88.

Priadi, A., Pasaribu, V. L. D., Virby, S., Sairin, S., \& Wardani, W. G. (2020). Penguatan Ekonomi Kreatif Berbasis Sumber Daya Desa Dikelurahan Rempoa. Abdi Laksana: Jurnal Pengabdian Kepada Masyarakat, 1(3), 356-35

Susanti, F., Ratnawati, W., \& ivan Jazwita, D. (2020). Literasi Digital Facebook dan Whatsapp terhadap Motivasi Belajar Generasi Milenial. Jurnal Lokabmas 
Loyalitas Kreativitas

Aldi Masyarakat Kreatif
P-ISSN 2722-2101, E-ISSN 2722-4201

Program Studi Ekonomi Manajemen Universitas Pamulang

Jurnal LOKABMAS Kreatif Vol.02,No.03.Nov 2021 Hal.79-84

Email:jurnalkreatif.manajemen@gmail.com
Kreatif: Loyalitas Kreatifitas Abdi Masyarakat Kreatif, 1(2), 35-40.

Susanti, F., Lisdawati, L., Andini, R., Setiawan, R., \& Ratnawati, W. (2020). Menanamkan Jiwa dan Semangat Kewirausahaan Persaingan Menghadapi di Era Globalisasi pada Guru dan Orangtua Murid Bimbingan Belajar Bimba Pamulang Tangerang Selatan. DEDIKASI PKM, 1(1), 95-100.

Susanti, F., Jaswita, D. I., \& Mardiana, S. (2020). PENGEMBANGAN POTENSI EKONOMI KEWIRAUSAHAAN IBU RUMAH TANGGA DALAM MENINGKATKAN EKONOMI MASYARAKAT KELURAHAN CEMPAKA PUTIH CIPUTAT. Jurnal Lokabmas Kreatif: Loyalitas Kreatifitas Abdi Masyarakat Kreatif, 1(1), 89-95.

Pulungan, Maimunah, Hindun, dkk. 2018. Teknologi Pengemasan dan Penyimpanan. Malang : UB Press
Riski Ananda. 2016. Peran Home Industri Dalam Meningkatkan Ekonomi Keluarga (Studi Kasus Home Industry Keripik Di Kelurahan Kubu Gabang). Riau. Jurnal JPM FISIP. Vol 3. No.2. Fakultas Ilmu Sosial Dan Ilmu Politik. Universitas Riau.

Saifuddin Zuhri. 2013. Analisis Pengembangan Usaha Kecil Home Industri Sangkar Ayam Dalam Rangka Pengentasan Kemiskinan. Lamongan. Jurnal Manajemen dan Akutansi. Vol.2 No.3. Fakultas Ekonomi. Universitas Islam Darul „Ulum Lamongan. Hal 48. 21 Sri Mulyaningsih, Tuju Widodo, Ilmu Pengetahuan Sosial, (Jakarta: Departemen Pendidikan Nasional, 2009), 62 .

Semariyani, Made AA, dkk. 2019. Pengemasan dan Strategi Pemasaran Produk Pangan di Desa Sulangi. Community Service Journal (CSJ), 2 (1) (2019), 23-28.

Tim Universitas Pamulang. 2020. http://unpam.ac.id/visi-dan-misi 